\title{
О.А. Шевчук
}

\section{ПАЛЕОГЕОГРАФІЧНІ УМОВИ В АЛЬБ-ТУРОНСЬКИЙ ЧАС НА ТЕРИТОРІЇ ВОЛИНО-ПОДІЛЛЯ ТА УКРАЇНСЬКОГО ЩИТА (ЗА ПАЛІНОЛОГІЧНИМИ ДАНИМИ)}

\section{O.A. Shevchuk \\ PALEOGEOGRAPHICAL CONDITIONS DURING THE ALBIAN AND THE TURONIAN IN THE TERRITORY OF VOLHYNIA-PODILIA AND THE UKRAINIAN SHIELD (BY PALYNOLOGICAL DATA)}

По данным палинологического анализа впервые реконструированы состав палеорастительности и палеогеографические условия на протяжении альб-туронского времени на территории Волыно-Подолии и Украинского щита. Сделаны выводы по палеоэкологическим групам. Приведены предположения о климате альбского, сеноманского и туронского времени. Ключевые слова: палеорастительность, палеогеографические условия, альб, сеноман, турон, Волыно-Подолия, Украинский щит.

Composition of paleoflora and paleogeographical conditions of Volhynia-Podilia and the Ukrainian Shield in the Albian and the Turonian have been reconstructed by palynological data. Paleoecological groups are considered. Assumptions concerning the climate during the Albian and the Turonian are made.

\section{ВСТУП}

Ступінь палеонтологічної вивченості крейдових відкладів західної частини України, а саме Волино-Поділля та Українського щита (УЩ) достатньо високий, але палінологічні дослідження в межах цих регіонів майже не проводились. У звязку з цим нами була зроблена спроба реконструювати палеогеографічні, еволюційні та палеоекологічні умови в крейдовий час на території за даними палінологічного аналізу.

\section{МАТЕРІАЛИ I МЕТОДИКА}

Матеріалом для наших досліджень були зразки порід крейди, відібрані з десяти відслонень на території Тернопільської області (район межиріччя Золота Липа - Коропець - Студенка), відслонення поблизу с. Завадівка (Тернопільська область), відслонення поблизу с. Китайгород, св. 39 (ділянка Перекалля, Волинь), св. 42 (с. Мала Глуша, КаміньКаширський район, Волинь), чотири св. 26, 27, 31, 33 (Тернопільська область) та чотири відслонення вздовж р. Дністер (поблизу м. Могилів-Подільський, с. Козлів, с. Бернашівка, Вінницька область та неподалік від с.м.т. Новодністровськ, Чернівецька область - стінка Новодністровської ГЕС) і шість відслонень на території Канівщини. Всього проаналізовано зразки крейди території Волино-Поділля з 12 відслонень і шести свердловин та території УЩ з 10 відслонень (див. рисунок).

Мацерація порід проводилась сепараційним методом В.П. Гричука.

\section{РЕЗУЛЬТАТИ ТА ОБГОВОРЕННЯ}

Флора крейди є однією з найцікавіших в розвитку рослинного царства. Саме до цього часу відноситься зародження палеокайнофітної флори, яка в порівняно малий проміжок часу охопила континентальні простори земної кулі [8].

До факторів, що впливають на формування рослинних угруповань, треба віднести зміни температури, вологості, складу грунту, тобто фактори, які залежать також від геологічних процесів в цілому. Трансгресії і регресії моря, коливальні рухи, вологість чи аридизація, потепління чи похолодання - все це могло бути причинами зміни рослинного покриву.

Результати палінологічного аналізу широко використовуються не тільки в цілях стратифікації, але і для відтворення історії розвитку давніх флор, реконструкції рослинності і палеогеографічних умов, палеофлористичного районування. Зміна спорово-пилкових комплексів у часі відображає етапність розвитку флори, еволюцію рослинного покриву, кліматичну зональність, палеогеографічні зміни [6].

Палінологічний метод в цьому відношенні має значну перевагу серед інших палеоботанічних методів. Палінологічні рештки, зокрема спори і пилок, в протилежність листовим відбиткам рослин добре зберігаються в континентальних, прибережно-морських і морських відкладах [8]. Спорово-пилкові комплекси відображають типи рослинності, що існувала на всіх елементах палеорельєфу, зональних і локальних областях - лісах, болотах, водоймах та ін. Палінологічні дані дозволяють оцінити не тільки систематичний склад, але і деякою мірою кількісне співвідношення основних груп і окремих видів в складі флори, що досягається підрахунком процентних співвідношень всіх компонентів, що входять до комплексу, враховуючи методичні розробки за дальністю транспортування пилку, ступенем його 


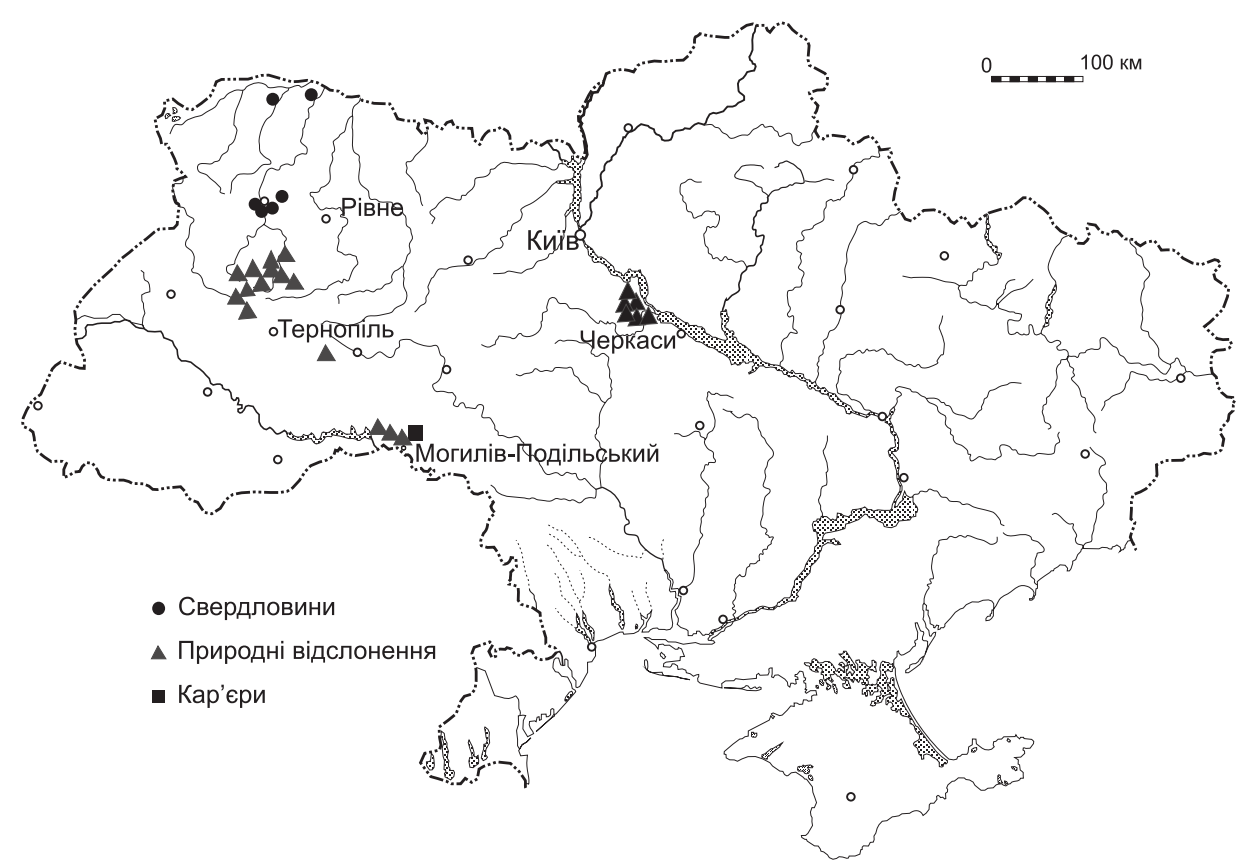

Рис. Карта фактичного матеріалу

збереженості в різних типах осадових порід та ін. Значний об'єм палеофлористичних та палінологічних даних, який опублікований в різноманітних роботах по різних регіонах земної кулі, дозволяє простежити загальні закономірності формування флор в широких масштабах і провести палеофлористичне районування. За характером рослинних угруповань вивчена територія відноситься до Європейської провінції Європейсько-Синійської палеофлористичної області [1, 2].

\section{Альбський час}

Палеогеографічні умови альбського морського басейну характеризувались нестабільністю. Неодноразові трансгресії і регресії моря привели до активізації гідрологічного режиму (течій, тимчасових водних потоків), розмивання раніш відкладених порід та утворення ділянок суходолу. Трансгресивні фази були в ранньому альбі, найбільш потужна, що наступали з південного сходу - в першій половині пізнього альбу (так звана альбсеноманська трансгресія), а регресивні фази - в середньому альбі і на межі альбу і сеноману [7].

Отже, на території Волино-Поділля в альбський час узбережжя такого острівного суходолу вкривали рідколісся, верхній ярус яких складали переважно хвойні (Pinus, Picea, Cedrus, Podocarpus) 3 підліском із гінкгових, та кипарисових і нечисленними цикадофітами. В трав'яному покриві росли різні папоротеподібні, плауни родин Ophioglossaceae, Osmundaceae, Polypodiaceae. Ці ліси займали прибережні рівнини. В більш вологих місцях зустрічались зарості папоротеподібних, де росли деревоподібні Dicksonia. Підлісок складали папоротеподібні родин Schizaeaceae, Gleicheniaceae. В трав'яному покриві, крім деяких папоротеподібних зустрічається мох Sphagnum. Характерною рисою альбських рослинних угруповань $€$ присутність найдавніших покритонасінних рослин - до 3-5\%. У водних басейнах переважають динофітові водорості Odontochitina, Oligosphaeridium, Spiniferites, Systematophora cretacea, Apteodinium, Ellipsodinium, Cribroperidinium та iн.

В альбський час територія східного та західного схилу УЩ зазнала морської трансгресії з південного заходу. Тут відбувається накопичення глауконітових пісків і пісковиків. Областю зносу є центральна частина УЩ, звідки і надходив теригенний матеріал. Таким чином, на початку ранньокрейдового часу (в перехідний період) [4] відбувається часткове підняття занурених в юрі ділянок щита (східний схил Ущ) В кінці ранньої крейди починається поступове занурення цієї території і розвиток трансгресії.

Рослинність пізнього альбу УЩ характеризується переважанням і різноманітяя голонасінних, присутні спорові рослини, склад покритонасінних нечисленний. На зміну схизейним, диксонієвим і матонієвим, що були домінуючими серед спорових В келовейському рослинному покриві, прийшли глейхенієві і циатейні папороті. Мохоподібні не складали окремих ландшафтів, але входили в різні рослинні угруповання. Палінологи відмічають в основному тільки сфагнові мохи. Але саме в альбський час сфагнові мохи досягали найбільшого поши- 


\section{О.А. ШЕВЧУК}

рення. Це пов'язано з широким розвитком у цей час алювіальних рівнини, на яких мохи росли з глейхенієвими папоротеподібними, або складали ділянки суцільних сфагнових боліт, що могли зустрічатись і в хвойних лісах. Помітні зміни відбулися і серед голонасінних. Зменшилась участь юрських форм - хейролепідієвих, яких витіснили соснові. Характерною рисою пізньоальбських рослинних угруповань $є$ присутність найдавніших покритонасінних рослин. У водних басейнах зустрічаються динофітові водорості Odontochitina, Oligosphaeridium, Spiniferites [16].

Знахідки мікрофітопланктону у відкладах крейди були приурочені в основному до мілководних прибережних фацій трансгресивних басейнів [3].

За екологічним складом в альбській Європейсько-Синійській палеофлористичній області, до якої і відноситься вивчена територія, домінуюча роль належала гігромезофільним рослинам. Нечисленні компоненти ксерофільної групи вагомої дії не мали. Серед рослин еврифільної групи субтропічної і помірно-теплої зон найбільшого значення набувають Pinus і Cedrus.

Аналізуючи флористичні та палеогеографічні дані з урахуванням геологічних даних, можна припустити, що на вивченій території в альбський час існував в основному лісовий тип рослинної формації. Клімат на території Волино-Поділля і ущ протягом альбського часу залишався здебільшого субтропічним, відмічались деякі коливання температур та вологи. Рослинність розвивалась в умовах перемінно вологого клімату 3 великою кількістю річних атмосферних осадків і невеликою річною амплітудою температур.

\section{Сеноманський час}

Палеогеографічні умови сеноманського морського басейну характеризувалися нестабільністю. Неодноразові трансгресії та регресії моря сприяли активізації гідрологічного режиму (течій, тимчасових водяних потоків), розмиванню раніше відкладених осадків та їх перевідкладенню, утворенню ділянок суходолу тощо. В сеноманський час на території Волино-Поділля встановлені два етапи трансгресій і регресій. Трансгресивні фази характерні для першої половини раннього і пізнього сеноману. Регресії відбувались на межі альбу - сеноману, а також наприкінці раннього та у середньому сеномані.

у ранньосеноманський час море вкривало всю територію Волино-Поділля. У цей час тут відкладаються переважно теригенні породи: глауконіт-кварцові і кварцові піски з нечисленними прошарками пісковиків, з гравієм чорних кременів, фосфоритів, інколи з дрібними конкреціями піриту. Подекуди зустрічаються прошарки спонго- літів і опок. У межиріччі Дністер - Прут залягають висококарбонатні форамініферово-коколітові мули, а на Середньому Придністров'ї відмічається кременисто-карбонатна товща $[5,9]$.

У ранньосеноманський час відбувається розмивання докрейдових відкладів і кори вивітрювання фундаменту західного схилу Ущ. На це вказують знахідки невеликих за розмірами лінз бейделітових глин у верхньому і нижньому опоко-трепелових шарах Середнього Придністров'я [5].

Відомостей про середньосеноманський час небагато. Середньосеноманські відклади на території західної частини платформної України значною мірою розмиті або перевідкладені, про що свідчать сумісні знахідки зональних середньосеноманських видів молюсків 3 ранньо- чи пізньосеноманськими. Тому до них умовно відносять нижні верстви вапняків (з призмами іноцерамів), які представлені вапняками слабко сцементованими, крихкими, місцями кремнеземистими, насиченими призмами зруйнованих черепашок іноцерамів з глауконітом і фосфоритами.

у другій половині сеноману відбувається трансгресія. Морський басейн поглиблюється та збільшує свою площу. Карбонатна седиментація охоплює морський басейн до кінця крейдового періоду. У пізньосеноманський час відкладаються іноцерамові і кремнеземисті вапняки, трепели, мергелі і крейда.

Рослинність сеноману Волино-Поділля характеризується переважанням і різноманітям голонасінних, присутні спорові рослини, участь покритонасінних поступово збільшується порівняно з альбським часом. Папоротеподібні представлені схизейними (Lygodiumsporites, Klukisporites), циатейними (Cyathidites), глейхенієвими (Gleichenia), матонієвими (Phlebopteris). Відмічені плаунові та мохоподібні. Характерною рисою сеноманських рослинних угруповань $€$ присутність найдавніших покритонасінних рослин: Pollenites, Triatrio-pollenites, Triatrio-pollenites rorubituites Pfl. та ін., а також близьких до сучасних платанових. В цей час умови існування динофітових водоростей погіршуються, що відбивається на видовому складі диноцист. У відкладах сеноману відмічені поодинокі форми диноцист. У водних басейнах зустрічаються динофітові водорості Odontochitina costata, Spiniferites, Cribroperidinium intricatum. Це може свідчити про пониження солоності вод басейну, а також, можливо, пов'язано з обмілінням моря. Цей факт підтверджує короткочасну регресію на вказаній території в пізньосеноманський час [5, 9, 13, 14].

УЩ у сеноманський час залишався найпотужнішою, тектонічно стабільною, малорухомою 
структурою платформної України. Блокова структура УЩ визначала палеорельєф суходолу, положення берегової смуги та особливості осадконакопичення. У сеноманський час море вкривало більшу його частину. Підвищені ділянки, які знаходилась у центральній його частині, утворювали суходіл і складались з декількох великих островів. Ядрами островів були Кіровоградська та Середньодніпровська брили. Поряд з великими островами існував ряд середніх островів, основними серед яких виступали Волинська, Подільська та Вовчанська брили. Крім того, нараховувалось безліч малих і тимчасових островів.

У межах УЩ у сеномані існувало ряд проток, що з'єднували басейн Дніпровсько-Донецької западини з басейнами Причорномор'я та Приазов'я. Положення проток визначалось розломними та депресійними зонами між брилами щита. Морський басейн Північного Причорномор'я з'єднувався з басейном Дніпровсько-Донецької западини протокою, що простягалась з південного заходу на північ, вздовж міжрозломної зони, утвореної Звіздаль-Заліським розломом між Подільською та Уманською брилами та Первомайським розломом між Уманською та Кіровоградською брилами Ущ.

Море, що вкривало УЩ, характеризувалося виключно мілководними умовами седиментації. Найбільші глибини були характерні для депресійних і розломних зон, а також тяжіли до крайових частин окремих брил щита. Межі поширення та потужність сеноманських відкладів на території УЩ контролювалися розмірами, формою та обрисами тектонічних депресій, в яких вони накопичувались. Так, сеноманські відклади Медвин-Сидорівської депресії, яка розташована на північно-східному схилі Ущ, повторюють її конфігурацію і мають широтне простягання на 40 км при ширині від 700 м до 12 км.

Сеноманські відклади на УЩ характеризуються двоповерховою будовою. Вони представлені переважно теригенними утвореннями ранньогосереднього сеноману та карбонатно-мергельною товщею пізнього сеноману. Відклади ранньогосереднього сеноману складені пісками зеленувато-сірими, дрібнозернистими, кварцовими і глауконіт-кварцовими з дрібними лусками слюди і спікулами губок, галечниками та пісковиками загальною потужністю до 40 м. Відклади пізнього сеноману - мергелями білими, крейдоподібними, у підошві світло-сірими, піскуватими з зернами кварцу (окатаними) і великою кількістю дрібних стяжінь фосфоритів і фауною молюсків загальною потужністю до 25 м. Максимальна потужність сеноману на щиті становить 51 м.
Рослинність сеноману УЩ характеризується переважанням і різноманітям голонасінних, присутні спорові рослини, склад покритонасінних поступово збільшується порівняно 3 альбським часом. Серед папоротеподібних відмічено зниження участі схизейних порівняно з альбським часом і збільшення кількості поліподієвих. Також присутні циатейні (Cyathidites), глейхенієві (Gleicheniidites), плауно- та мохоподібні. Хвойні в цей час досить поширені. Характерним є те, що хвойні пристосовані до більш засушливих умов і потребують для розвитку багато сонячного світла. Отже, у складі хвойних відмічається зникнення більш вологолюбних форм. Покритонасінні рослини насамперед займали підвищені ділянки суші і пізніше проникали в низини, що були більш вологі. Платанові утворювали по алювіальних долинах листопадні ліси.

На території могилів-подільської частини західного схилу УЩ у водних басейнах в сеноманський час збільшується кількість і різноманіття динофітових водоростей порівняно з альбським часом. А на території Волині відмічається менша участь динофітових водоростей. Це може бути пов'язано 3 тим, що море, яке вкривало УЩ, характеризувалося виключно мілководними умовами седиментації і наступали трансгресії з південного сходу.

За екологічним складом у сеноманській Європейсько-Синійській палеофлористичній області, до якої і відноситься вивчена територія, домінуюча роль належала гігромезофільним рослинам. Нечисленні компоненти ксерофільної групи не мають вагомого значення. Серед рослин еврифільної групи субтропічної і помірно-теплої зон домінують Pinus і Cedrus.

Порівнюючи флори альбського і сеноманського часів, можна сказати, що в більш молодих комплексах відбувається скорочення вмісту папоротеподібних і голонасінних рослин, що відносяться до тропічних і субтропічних форм. Зменшується кількість теплолюбних папоротів: Gleichenia, Schizaeceae, майже зникають Сусаdaceae, Bennettitaceae, особливо це стосується давніх хвойних Classopollis. На зміну їм приходять комплекси голонасінних i спорових рослин, що характерні для більш прохолодних місць існування (Cedrus, Sphagnum). Аналізуючи флористичні та палеогеографічні дані з урахуванням геологічних даних, можна припустити, що на вивченій території в сеноманський час існував в основному лісовий тип рослинної формації.

Клімат на території Волино-Поділля і УЩ протягом сеноманського часу залишався переважно субтропічний, але більш прохолодніший ніж в альбський час, але безсумнівно безморозний і вологий. 


\section{О.А. ШЕВЧУК}

\section{Туронський час}

Туронський час - це важливий етап у розвитку епіконтинентальних морських басейнів території платформної України. В регіоні остаточно формуються умови нового етапу розвитку пізньокрейдових басейнів - пізньосеномансько-маастрихтського, що призводить до масового розквіту морських мікроорганізмів з карбонатним скелетом ("планктонний вибух") та накопичення потужної товщі писальної крейди.

Порівняно з сеноманським часом скорочується площа басейнів Волино-Поділля. Більшу частину туронського часу територія Поділля залишалась суходолом. Море в цей час вкривало територію Волині. В туронському морському басейні на вивченій території існує декілька островів.

у Передкарпатському та Львівсько-Люблінському прогинах розвинуті переважно вапняки 3 прошарками вапнистих глин потужністю до 230 м. Уздовж р. Дністер поширені кремнеземисті вапняки, трепели, халцедоноліти. Спостерігаються прошарки кременю та бентонітових глин. На Волині туронські відклади представлені здебільшого писальною крейдою, вапняками та мергелями [5]. Максимальні потужності відкладів - до 120 м.

Рослинність турону Волино-Поділля характеризується переважанням і різноманітям голонасінних та покритонасінних рослин, присутні спорові. Папоротеподібні представлені в основному поліподієвими (Polypodiaceae) та глейхенієвими (Gleichenia). У туронський час домінують голонасінні рослини - до 50\%. Здебільшого це представники родини Pinaceae: Abies, Pinus (Pinus trivialis Naum., P. vulgaris Naum., P. nigraeformis Bolch). Присутні голонасінні родин Ginkgocycadaceae, Cupresaceae i Araucariaceae. Кипарисові та араукарієві займають до 5\%. Характерною рисою туронських рослинних угруповань $€$ збільшення відсоткового вмісту та таксономічного різномаїтя найдавніших покритонасінних рослин (до 25\%) порівняно з сеноманським часом. Поряд з давніми формами Triatriopollenites та Clavatipollenites sp., що становлять 3\%, присутні покритонасінні, близькі до сучасних. Так, 3 групи деревних відмічені Betulaceae (7\%), Juglandaceae (3\%). Присутні гриби (конідії). У водних басейнах зустрічаються динофітові водорості Odontochitina operculata, O. costata, Coronofera oceanica, Spiniferites i iн. [10, 12, 15].

УЩ у туронський час майже повністю залишався суходолом з континентальними умовами розвитку. Поширення моря на щиті контролювалось його розломно-блоковою структурою. Морем були вкриті понижені ділянки щита, зокрема значна частина
Приазовського кристалічного масиву (КонкськоЯлинська западина [5]), а також прирозломні зони, грабени, депресії та крайові абразійні долини. Відклади турону на території Ущ представлені мергелем та білою писальною крейдою у нижній частині, а у верхній - білою писальною крейдою. Потужність відкладів коливається від 0,1 до 15 м.

Рослинність турону УЩ характеризується переважанням і різноманітям голонасінних та покритонасінних рослин, присутні спорові. В складі папоротеподібних глейхенієві та схизейні майже повністю втрачають своє значення. Вони витісняються поліподієвими. Серед голонасінних продовжують відігравати важливу роль соснові. Кількість покритонасінних у туронський час на території Ущ значно зростає, і систематичний склад їх стає більш різноманітним. Відмічаються представники Betulaceae, Juglandaceae, Liliaсеае, а також стає більшою кількість видів, що не мають аналогів серед сучасних рослин.

Отже, в туронський час узбережжя острівного суходолу вкривали рідколісся, верхній ярус яких складали переважно хвойні (в основному Pinus, рідше Picea, Cedrus, Abies, Podocarpus), а також деякі види деревних покритонасінних. Рідше зустрічаються таксодієві з підліском із гінкгових та кипарисових і нечисленними цикадофітами. В трав'яному покриві росли папоротеподібні родини Polypodiaceae. Ці ліси займали прибережні рівнини. В більш вологих місцях зустрічались зарості папоротеподібних, де росли деревоподібні Dicksonia. Підлісок складали папоротеподібні родини Gleicheniaceae та деякі вологолюбні покритонасінні рослини. В трав'яному покриві, крім деяких папоротеподібних, зустрічається мох Sphagnum, плавуни, а також покритонасінні. Характерною рисою туронських рослинних угруповань $€$ збільшення найдавніших покритонасінних рослин - до 30\%. У водних басейнах переважають динофітові водорості Odontochitina operculata, O. costata, Spiniferites та ін.

За екологічним складом у туронській Європейсько-Синійській палеофлористичній області, до якої i відноситься вивчена територія, домінуюча роль належала гігромезофільним рослинам. Нечисленні компоненти ксерофільної групи вагомої дії не відіграють (тільки Cupressaceae). Серед рослин еврифільної групи субтропічної і помірно-теплої зон найбільше значення мають Pinus i Cedrus, а також збільшується участь покритонасінних цієї групи.

Порівнюючи флори сеноманського і туронського часів, можна сказати, що в більш молодих комплексах відбувається скорочення вмісту папоротеподіб- 
них і голонасінних рослин, що відносяться до тропічних і субтропічних форм. Зменшується кількість теплолюбних папоротів Gleichenia і майже зникають Schizaeceae. На зміну їм приходять комплекси голонасінних і спорових рослин, що характерні для більш прохолодних місць існування (Cedrus, Sphagnum).

Аналізуючи флористичні та палеогеографічні дані з урахуванням геологічних даних, можна припустити, що на вивченій території в туронський час існував в основному лісовий тип рослинної формації. Клімат на території Волино-Поділля і УЩ протягом туронського часу залишався переважно субтропічний, але більш прохолодніший, ніж в альбський і сеноманський часи, але безсумнівно безморозний і вологий.

\section{ВИСНОВКИ}

Альб-туронські флори Волино-Поділля та УЩ характеризуються розвитком мохоподібних, плаунових, селягінелієвих, папоротеподібних, голонасінних. В альбський час у межах вивченої території встановлена поява покритонасінних рослин, що продукували пилок одноборозного типу. В сеномані морфологічне різноманіття цих рослин зростає: були присутні покритонасінні рослини, що продукували пилок триборозного типу, а також відмічено наявність рослин, що визначені за природною класифікацією і є близькими до деяких сучасних покритонасінних. У туронський час їх участь зростає. Послідовність появи в часі цих різноманітних морфологічних типів підтверджує загальну закономірність в розвитку цих рослин на земній кулі. Покритонасінні рослини - представники нової кайнофітної флори, набувають значного розквіту, тут присутні різні родини, що займають різні екологічні ніші [11].

В складі флори простежуються такі зміни: поступово зменшується кількість гігромезофітів, хоча роль їх все ж таки залишається домінуючою. Можливо, в пізньокрейдовий час у зв'язку з температурними крайностями умов проживання водоростей у високих широтах у них спостерігається тенденція до збільшення розмірів тіла порівняно з динофітовими водоростями юрського та ранньокрейдового часів. Цей фактор ще раніше був відмічений А.Н. Криштофовичем [8].

Клімат протягом альб-сеноманського часу залишався субтропічним, в сеноман-туронський час відмічається деяке похолодання.

1. Вахрамеев В.А. Юрские и меловые флоры и климаты Земли. - М.: Наука, 1988. - 216 с.

2. Вахрамеев В.А., Добрускина И.А., Заклинская Е.Д., Мейен С.В. Палеозойские и мезозойские флоры Евра- зии и фитогеография этого времени. - М.: Наука, 1970. - 427 c.

3. Возженникова Т.Ф. Диноцисты и их стратиграфическое значение. - Новосибирск: Наука, 1979. - 224 с.

4. Выржиковский P.P. К геологии южной части Каневского уезда // Пробл. Киев. о-ва естествоиспытателей за 1915 г. - Киев, 1916. - С. 77-88.

5. Гаврилишин В.И., Пастернак С.И., Розумейко С.В. Стратиграфические подразделения меловых отложений платформенной части запада Украины.- Львов, 1991. - 52 с. - (Препр. АН УССР / Ин-т геологии и геохимии горючих ископаемых; № 91-І).

6. Гольберт А.Б. и др. Палеоклиматы Сибири в меловом и палеогеновом периодах. - М.: Недра, 1977. - 108 с.

7. Іванников О.В. Геологія району Канівських дислокацій. - К.: Наук. думка, 1966. - 95 с.

8. Криштофович А.Н. Эволюция растительного покрова в геологическом прошлом и ее основные факторы // Материалы по истории флоры и растительности СССР. - 1946. - Вып. 2.

9. Пастернак C.І., Сеньковський Ю.М., Гаврилишин B.І. Волино-Поділля у крейдовому періоді. - К.: Наук. думка, 1987. - 260 с.

10. Шевчук Е.А. Палинологические исследования меловых отложений междуречья Золотая Липа - Коропец (Западная Украина) // Палинология: теория и практика: XI Всерос. палинолог. конф. - М., 2005. - С. 281-282.

11. Шевчук Е.А. Пыльца древнейших покрытосеменных растений на территории Волыно-Подолии // Международная палеоботаническая конференция. - М., 2005. С. 75-76.

12. Шевчук О.А. Біостратиграфія крейдових відкладів Волині за палінологічними даними // Біостратиграфічні критерії розчленування та кореляції відкладів фанерозою України. - К., 2005. - С. 84-91.

13. Шевчук Олена. Знахідки цист динофлагелят в крейдових відкладах Волино-Поділля // Палеонтол. зб. 2005. - № 37. - С. 84-88.

14. Шевчук Е.А. Динофитовые водоросли из меловых отложений северо-западной Украины (Волынь) // Проблеми біостратиграфії нижнього протерозою і фанерозою України. - К., 2006. - С. 118-123.

15. Шевчук Олена. Палінологічні дослідження верхньокрейдових відкладів Поділля // Палеонтол. зб. 2006. - № 38. - С. 81-87.

16. Шевчук О.А. Палеогеографічні умови на східному схилі Українського щита в келовейський та ранньокрейдовий час (за палінологічними даними) // Біостратиграфічні основи побудови стратиграфічних схем фанерозою України. - К., 2008. - С. 101-106.

Інститут геологічних наук НАН України, Київ 